\title{
Primary torsion dystonia: the search for genes is not over
}

Department of Clinical Neurology, Institute of Neurology, London, UK

P R Jarman

E M Valente

$\mathrm{N}$ W Wood

Instituto di Medicina Sperimentale, CNR,

Roma, Italy

$\mathrm{N}$ del Grosso

M Frontali

Department of

Neurology, University

Hospital, Düsseldorf,

Germany

B Leube

G Auburger

Institute of Neurology,

Universita Cattolica

del S Cuore, Roma,

Italy

E Cassetta

A R Bentivoglio

A Albanese

Department of

Neurology, Royal

Adelaide Hospital,

Australia

H M Waddy

Mayo Clinic

Jacksonville, Florida,

USA

R J Uitti

Department of

Neurology, Mayo

Clinic, Rochester, MN,

USA

D M Maraganore

Department of

Neurology,

Columbia-Presbyterian

Medical Center, New

York, NY, USA

S B Bressman

T G Nygaard

Correspondence to: Dr Nicholas Wood,

Department of Clinical

Neurology, Institute of

Neurology, Queen Square,

London, WC1N 3BG, UK

Telephone 0044171837

3611; fax 0044171278

5616 .

Received 22 June 1998 and in revised form

23 March 1999

Accepted 6 May 1999

P R Jarman, N del Grosso, E M Valente, B Leube, E Cassetta, A R Bentivoglio, H M Waddy, R J Uitti, D M Maraganore, A Albanese, M Frontali, G Auburger, S B Bressman, N W Wood, T G Nygaard

\begin{abstract}
A GAG deletion in the DYT1 gene accounts for most early, limb onset primary torsion dystonia (PTD). The genetic bases for the more common adult onset and focal PTD are less well delineated. Genetic loci for an "intermediate dystonia" phenotype and for torticollis, named DYT6 and DYT7 respectively, have recently been mapped in single families. To evaluate the contribution of these genetic loci to other families with familial "nonDYT1" dystonia five large families with dystonia were studied using genetic markers spanning the DYT6 and DYT7 regions. There was no evidence of linkage to either locus in any family. These findings illustrate the genetic heterogeneity of the dystonias and indicate the existence of one or more as yet unmapped genes for dystonia. Large collaborative efforts will be required to identify these, and additional genes, causing PTD.

(F Neurol Neurosurg Psychiatry 1999;67:395-397)
\end{abstract}

Keywords: primary torsion dystonia

Dystonia is characterised by involuntary muscle contractions which often cause twisting and repetitive movements or abnormal postures. ${ }^{1}$ In the absence of an identified cause or other neurological abnormalities, this syndrome had been termed "idiopathic torsion dystonia". However, with the mapping and identification of several genes causing idiopathic dystonia, the term primary torsion dystonia (PTD) is now preferred. ${ }^{2}$

DYT1, on chromosome 9q34, was the first PTD gene mapped. A three base pair, GAG (glutamic acid) deletion in this gene, which encodes an ATP binding protein TorsinA accounts for almost all early onset generalised PTD in several ethnic groups. ${ }^{3}$ The typical clinical features of DYT1 associated dystonia are limb onset and spread to the trunk which rarely affects craniofacial muscles. ${ }^{5}{ }^{6} \mathrm{By}$ contrast, late onset PTD tends to begin in craniocervical muscles or an arm and usually remains focal or segmental in distribution. There has been no relation found between DYT1 and dystonia in families with prominent craniofacial involvement, ${ }^{3578}$ or late onset, focal, cervical dystonia (torticollis). ${ }^{9}$ The genetic basis of most adult onset PTD has not been established. Up to $25 \%$ of patients with focal dystonia have an affected relative, ${ }^{10}$ suggesting the existence of one or more dominantly inherited genes with reduced penetrance.

Two loci causing these "non-DYT1" dystonias have now been mapped. Leube et al mapped DYT7, causing adult onset focal PTD, to chromosome $18 \mathrm{p},{ }^{11}$ and Almasy et al mapped DYT6, causing an "intermediate" phenotype with features common to both early and late onset PTD, to the pericentromeric region of chromosome $8 .{ }^{12}$ As a first step in evaluating the contribution of DYT6 and DYT7 in PTD, we have analysed five families with non-DYT1 PTD with markers spanning these regions on chromosomes 8 and 18 .

\section{Patients and methods}

PATIENTS

The clinical details of the five families studied have been reported previously. ${ }^{8}{ }^{13-15}$ Participating family members were examined by a neurologist and the examination was videotaped. Writer's cramp was tested for in all patients. Diagnosis was confirmed by independent review of the tapes. Secondary dystonia was excluded with appropriate investigations.

DNA ANALYSIS

DNA was extracted from peripheral blood leucocytes using standard techniques. Microsatellite markers were amplified from genomic DNA using the polymerase chain reaction. The candidate regions containing the DYT6 and DYT7 loci are large (40-50 cM). To fully exclude either region for each family required a marker density which varied with the size of the family and the number of recombinations with affected members in each region. For the DYT6 region, microsatellite markers between markers D8S1791 (8p21) and D8S1475 (8q22) were analysed. For the DYT7 candidate region, markers from 18pter to D18S843 were analysed. The number and average interlocus spacing of markers typed for each family are given in table 1. All map distances are according to the 
Table 1 Summary of microsatellite maker numbers and density at each locus

\begin{tabular}{|c|c|c|c|c|c|}
\hline Family & $\begin{array}{l}1 \\
\text { Uitti and } \\
\text { Maraganore }^{14}\end{array}$ & $\begin{array}{l}2 \\
\text { Bressman } \\
\text { et al }\end{array}$ & $\begin{array}{l}3 \\
\text { Bentivoglio } \\
\text { et al }^{8}\end{array}$ & $\begin{array}{l}4 \\
\text { Parker }^{15}\end{array}$ & $\begin{array}{l}5 \\
\text { Bressman } \\
\text { et al }\end{array}$ \\
\hline \multicolumn{6}{|c|}{ Number of markers typed: } \\
\hline Chromosome 8 & 14 & 13 & 10 & 10 & 17 \\
\hline Chromosome 18 & 7 & 21 & 14 & 12 & 10 \\
\hline \multicolumn{6}{|c|}{ Average marker spacing $(\mathrm{cM})$ : } \\
\hline Chromosome 8 & 3.4 & 3.7 & 4.9 & 4.9 & 2.8 \\
\hline Chromosome 18 & 7.8 & 2.3 & 3.6 & 4.2 & 5.2 \\
\hline
\end{tabular}

Marshfield Clinic genetic maps at: http:// www.marshmed.org/genetics/

\section{LINKAGE ANALYSES}

In each family, pairwise LOD scores were calculated for dystonia and markers in the candidate regions using the MLINK program. ${ }^{16}$ Multipoint analysis was performed using the VITESSE program..$^{17}$ An autosomal dominant model of inheritance was used with a disease gene frequency of 0.0001 . Only definitely affected family members were classified as "affected" for linkage and unaffected and possibly affected family members were classified as phenotype "unknown". This conservative, "affecteds only", methodology was used for all analyses to avoid bias from the inclusion of possibly affected members or incorrect estimation of penetrance or age at onset. The identical twins in family 1 were considered as one person for the purposes of linkage. Marker allele scoring was uniform across all families and frequencies were estimated by allele counting with all genotyped subjects. Under the null hypothesis of no linkage, this gives unbiased estimates of allele frequencies.

\section{Results}

PATIENTS

The clinical features of all five families have been reported in detail. ${ }^{8{ }^{13-15}}$ None of the families have any apparent Ashkenazi Jewish heritage. A summary of the clinical characteristics of each family is given below. Selected clinical details are presented in table 2 .

Family 1 is American of German origin. ${ }^{14}$ Of the 22 family members examined, five had definite cervical dystonia, including a pair of monozygotic twins. Five had possible cervical dystonia including two obligate gene carriers. Dystonia remained focal in all cases.

Family 2 is American of German origin'; with no known relationship to family 1 . Of the 21 patients examined, seven had definite dystonia and four possible dystonia. Among the definitely affected members six had onset of symptoms in the cervical muscles and one in the arm. Dystonia remained focal in all but one patient, in whom there was spread to an arm (segmental dystonia).

Family 3 is Italian. ${ }^{8}$ Among the 45 family members examined, eight had definite dystonia and six had probable dystonia. Symptoms began in the craniocervical region in six of the definitely affected patients and in the arms in the remaining two. There had been progression to mild generalised dystonia in two patients and segmental dystonia in four at the time of last examination.

Family 4 is Australian of English ancestry. ${ }^{15}$ At the latest assessment 11 family members were definitely affected among the 36 examined. Spasmodic dysphonia was prominent, being present in all affected members and the presenting feature in most. Dystonia progressed to become generalised in eight patients and segmental in one. Two siblings had Wilson's disease; both had dystonia indistinguishable from other family members; they were therefore classified as affected.

Family 5 is American of German ancestry, unrelated to families 1 or $2 .{ }^{13}$ Of the 53 family members examined seven had definite dystonia, three probable dystonia, and 10 possible dystonia. Symptoms began in the neck in six definitely affected members and progressed to involve cranial and cervical muscles in all seven. Dysarthria or dysphonia were present in five members. One family member developed generalised dystonia; symptoms remained segmental or multifocal in the remainder.

\section{LINKAGE ANALYSES}

We found obligate recombinations between dystonia and the informative markers across the regions spanning DYT6 and DYT7 in all five families. Multipoint analyses excluded these regions (LOD scores $\leqslant-2$ ) except for portions of the DYT6 region in family 1 . The

Table 2 Summary of selected clinical features in DYT6/DYT7 kindreds and families studied

\begin{tabular}{|c|c|c|c|c|c|c|c|}
\hline Family & $\begin{array}{l}\text { Almasy et al }{ }^{12} \\
\text { (two families) }\end{array}$ & Leube et $a l^{11}$ & $\begin{array}{l}1 \\
\text { Uitti and } \\
\text { Maraganore }\end{array}$ & $\begin{array}{l}2 \\
\text { Bressman et } a l^{9}\end{array}$ & $\begin{array}{l}3 \\
\text { Bentivoglio et } a l^{8}\end{array}$ & $\begin{array}{l}4 \\
\text { Parker }^{15}\end{array}$ & $\begin{array}{l}5 \\
\text { Bressman et al }\end{array}$ \\
\hline Genetic locus & Chr 8 (DYT6) & Chr 18 (DYT7) & Not mapped & Not mapped & Not mapped & Not mapped & Not mapped \\
\hline Mean age at onset (y (range)) & $\begin{array}{l}19(5-35) \\
18(6-38)\end{array}$ & $43(28-70)$ & $35(18-49)$ & $31(15-62)$ & $16(5-40)$ & N/A $(13-37)$ & $28(7-50)$ \\
\hline Mean duration (y (range)) & $\begin{array}{l}28(2-69) \\
17(4-24)\end{array}$ & $10(4-31)$ & $19(7-38)$ & $15(1-44)$ & $41(5-66)$ & N/A & $28(10-50)$ \\
\hline $\begin{array}{l}\text { Definitely affected members } \\
\text { Body part first affected. }\end{array}$ & 15 & 7 & 5 & 7 & 8 & 11 & 7 \\
\hline Cranial & 4 & 1 & - & - & 0 & 8 & 1 \\
\hline Cervical & 3 & 6 & 5 & 6 & $6^{\star}$ & 2 & $6 \dagger$ \\
\hline Arm & 7 & - & - & 1 & 2 & - & - \\
\hline Leg & 1 & - & - & - & - & 1 & 1 \\
\hline Craniocervical involvement: & & & & & & & \\
\hline Cranial (larynx) & $11(7)$ & $1(1)$ & - & $1(1)$ & $7(-)$ & $10(10)$ & $7(2)$ \\
\hline Cervical & 5 & 6 & 5 & 6 & 7 & 2 & 7 \\
\hline Total & 13 & 7 & 5 & 6 & 7 & 10 & 7 \\
\hline
\end{tabular}

*Three cases had craniocervical onset.

tThree cases had craniocervical onset.

$\mathrm{N} / \mathrm{A}=$ Information not available. 
Table 3 Two point LOD scores for selected chromosome 8 and 18 markers spanning the DYT6 and DYT7 loci

\begin{tabular}{|c|c|c|c|c|c|c|}
\hline & $\begin{array}{l}\text { LOD score } \\
\text { at } \theta=\end{array}$ & 0 & 0.05 & 0.1 & 0.2 & 0.3 \\
\hline \multicolumn{7}{|l|}{ Family 1 : } \\
\hline \multirow[t]{3}{*}{ Chromosome 8} & D8S1791 & -3.15 & -1.43 & -0.88 & -0.39 & -0.15 \\
\hline & D8S260 & -2.8 & -0.23 & -0.01 & 0.1 & 0.08 \\
\hline & D8S286 & -2.8 & -0.19 & 0.02 & 0.12 & 0.09 \\
\hline \multirow[t]{3}{*}{ Chromosome 18} & D18S59 & -3 & -1.29 & -0.76 & -0.3 & -0.11 \\
\hline & D18S452 & -6.19 & -1.44 & -0.89 & -0.39 & -0.15 \\
\hline & D18S843 & -2.7 & -0.72 & -0.44 & -0.19 & -0.08 \\
\hline \multicolumn{7}{|l|}{ Family 2: } \\
\hline \multirow[t]{3}{*}{ Chromosome 8} & D8S1791 & -2.2 & 0.07 & 0.23 & 0.24 & 0.13 \\
\hline & D8S1113 & -2.2 & -1.15 & -0.67 & -0.25 & -0.09 \\
\hline & D8S279 & -2.5 & -1.15 & -0.63 & -0.2 & -0.04 \\
\hline \multirow[t]{3}{*}{ Chromosome 18} & D18S59 & -2.75 & -0.97 & -0.63 & -0.29 & -0.12 \\
\hline & D18S54 & -2.5 & -1.17 & -0.67 & -0.25 & -0.09 \\
\hline & D18S391 & -3.1 & -0.72 & -0.44 & -0.19 & -0.08 \\
\hline \multicolumn{7}{|l|}{ Family 3 : } \\
\hline \multirow[t]{3}{*}{ Chromosome 8} & D8S1791 & -5.48 & -1.81 & -1.3 & -0.79 & -0.45 \\
\hline & D8S260 & -5.48 & -1.28 & -0.73 & -0.27 & -0.09 \\
\hline & D8S286 & -2.53 & -0.63 & -0.43 & -0.29 & -0.21 \\
\hline \multirow[t]{3}{*}{ Chromosome 18} & D18S59 & -5.48 & -1.81 & -1.3 & -0.79 & -0.45 \\
\hline & D18S52 & -2.85 & -1.53 & -0.99 & -0.49 & -0.24 \\
\hline & D18S452 & -5.61 & -1.4 & -0.93 & -0.55 & -0.34 \\
\hline \multicolumn{7}{|l|}{ Family 4: } \\
\hline \multirow[t]{3}{*}{ Chromosome 8} & D8S1791 & -5.84 & -2.99 & -2.07 & -0.98 & -0.42 \\
\hline & D8S260 & -4.68 & -1.89 & -1.23 & -0.6 & -0.31 \\
\hline & D8S286 & -5.5 & -0.91 & -0.43 & -0.07 & 0.05 \\
\hline \multirow[t]{3}{*}{ Chromosome 18} & D18S59 & -4.33 & -1.94 & -1.29 & -0.51 & -0.16 \\
\hline & D18S52 & -4.05 & -1.73 & -1.16 & -0.48 & -0.17 \\
\hline & $\mathrm{D} 18 \mathrm{~S} 452$ & -7.69 & -2.63 & -1.82 & -0.78 & -0.25 \\
\hline \multicolumn{7}{|l|}{ Family 5: } \\
\hline \multirow[t]{3}{*}{ Chromosome 8} & D8S1791 & -3.14 & -1.54 & -0.99 & -0.47 & -0.22 \\
\hline & D8S260 & -5.47 & -1.11 & -0.62 & -0.25 & -0.1 \\
\hline & D8S1119 & -5.96 & -1.57 & -1.01 & -0.48 & -0.22 \\
\hline \multirow{3}{*}{ Chromosome 18} & D18S59 & -5.45 & -1.62 & -0.87 & -0.28 & -0.08 \\
\hline & D18S1154 & -5.13 & -0.58 & -0.16 & 0.08 & 0.05 \\
\hline & D18S967 & -5.45 & -1.48 & -0.98 & -0.53 & -0.3 \\
\hline
\end{tabular}

LOD scores for these regions were $<-1.5$. Recoding of the siblings with Wilson's disease in family 4 as phenotype unknown did not affect the exclusion. Pairwise LOD scores for selected markers are given in table 3 .

\section{Discussion}

These data provide compelling evidence for the existence of one or more genes in addition to DYT1, DYT6, and DYT7 as a cause for PTD. Although the experience with DYT1 indicates that early onset, limb PTD is genetically relatively homogeneous, the great majority being accounted for by mutations of torsinA, such is not the case for adult onset cervical PTD. ${ }^{34}$

Considerable genetic diversity underlies the phenotype of adult onset, predominantly craniocervical, dystonia. Dystonia starting in or confined to head and neck muscles may result from mutations of one or more as yet unidentified genes segregating in the families studied here, as well as from DYT6 and DYT7 mutations. Even DYT1 may rarely present in this manner. ${ }^{5}$ The presence of allelic association at D18S1098 in patients with torticollis living in the same region of northern Germany as the family studied to map DYT $7,{ }^{18}$ suggests that this may be an important gene in some geographical regions. However, the identical phenotype in families 1 and 2, both of German origin, is unrelated to DYT7. By contrast with the families studied here the low recurrence risk of dystonia in relatives of most patients with torticollis might imply that other, low penetrance, mutation(s) or non-genetic factors may underlie most of this condition. ${ }^{19}$

Large families with non-DYT1 PTD suitable for linkage analysis are comparatively rare. Further genetic linkage studies to identify the gene or genes underlying dystonia in these families are presently underway.

We are grateful to all participating patients and family members. This research was supported by a Wellcome Research Training Comitato Promotore Telethon Grant E499 (AA, EC and ARB),

1 Fahn S, Marsden CD, Calne DB. Classification and investigation of dystonia. In: Marsden CD, Fahn S, eds. Movement disorders 2. London: Butterworths, 1987:332-58.

2 Fahn S, Bressman S, Marsden CD. Classification of dystonia. Mov Disord 1997;12:3-4.

3 Ozelius LJ, Hewett JW, Page CE, et al. The early-onset torsion dystonia gene (DYT1) encodes an ATP-binding protein. Nat Genet 1997;17:40-8.

4 Valente EM, Warner TT, Jarman PR, et al. The role of DYT1 in primary torsion dystonia in Europe. Brain 1998; 121:2335-9.

5 Bressman SB, de Leon D, Kramer PL, et al. Dystonia in Ashkenazi Jews: clinical characterization of a founder mutation. Ann Neurol 1994;36:771-7.

6 Kramer PL, Heiman GA, Gasser T, et al. The DYT1 gene Kramer PL, Heiman GA, Gasser T, et al. The DYT1 gene
on 9q34 is responsible for most cases of early limb-onset diopathic torsion dystonia in non-Jews. Am f Hum Genet 1994;55:468-75

7 Ahmad F, Davis MB, Waddy HM, et al. Evidence for locus heterogeneity in autosomal dominant torsion dystonia. Genomics 1993;15:9-12.

8 Bentivoglio AR, Del Grosso $\mathrm{N}$, Albanese A, et al. Non-DYT1 dystonia in a large Italian family. $\mathcal{F}$ Neurol Neurosurg Psychiatry 1997;62:357-60.

9 Bressman SB, Warner TT, Almasy L, et al. Exclusion of the DYT 1 locus in familial torticollis. Ann Neurol 1996;40: 681-4.

10 Waddy HM, Fletcher NA, Harding AE, et al. A genetic study of idiopathic focal dystonias. Ann Neurol 1991;29: $320-4$.

11 Leube B, Rudnicki D, Ratzlaff T, et al. Idiopathic torsion dystonia: assignment of a gene to chromosome $18 \mathrm{p}$ in a German family with adult onset, autosomal dominant nheritance and purely focal distribution. Hum Mol Genet 1996;5:1673-7

12 Almasy L, Bressman SB, Raymond D, et al. Idiopathic torsion dystonia linked to chromosome 8 in two Mennonite families. Ann Neurol 1997;42:670-3.

13 Bressman SB, Heiman GA, Nygaard TG, et al. A study of idiopathic torsion dystonia in a non-Jewish family: evidence for genetic heterogeneity. Neurology 1994;44:283-7.

14 Uitti RJ, Maraganore DM. Adult onset familial cervical dystonia: report of a family including monozygotic twins. Mov Disord 1993;8:489-94.

15 Parker N. Hereditary whispering dysphonia. $\mathcal{F}$ Neurol Neurosurg Psychiatry 1985;48:218-24.

16 Lathrop GM, Lalouel JM. Efficient computations in multilocus linkage analysis. Am f Hum Genet 1988;42:498-505.

7 O'Connell JR, Weeks DE. The VITESSE algorithm for rapid exact multilocus linkage analysis via genotype et-recording and fuzzy inheritance. Nat Genet 1995;11: $402-8$

18 Leube B, Hendgen T, Kessler KR, et al. Sporadic focal dysonia in northwest Germany: molecular basis on chromosome 18p. Ann Neurol 1997;42:111-4.

19 Waddy HM, Fletcher NA, Harding AE, et al. A genetic study of idiopathic focal dystonias. Ann Neurol 1991;29: 320-4. 